\title{
Elevation of Serum Apolipoprotein B after Successful Eradication of Hepatitis C Virus in Patients with Chronic Hepatitis C Treated by IFN-Based Therapy
}

\author{
Kogame M, Ishii K, Kanayama K*, Shinohara MI and Sumino Y
}

Division of Gastroenterology and Hepatology, Department of Internal Medicine, Toho University School of Medicine, Faculty of Medicine, Tokyo, Japan

\begin{abstract}
Background: Hepatitis C Virus (HCV) infection is closely tied to the lipid metabolism of liver cells. We recently reported that serum levels of LDL- and VLDL-cholesterol (Cho) increased in patients with Chronic Hepatitis C (CHC) showing Sustained Virologic Response (SVR) after treatment with interferon (IFN)-based therapy. LDL- and VLDLCho contained apolipoprotein (apo)-B synthesized in the liver as a major protein component. The goal of the present study was to clarify how serum lipid markers change in CHC patients showing SVR after treatment with IFN-based therapy.
\end{abstract}

Patients and methods: The study included 121 consecutive patients with $\mathrm{CHC}$ infected with HCV genotype 1 ( $n=66$, male/female: $40 / 26$ ) or HCV genotype $2(n=55$, male/female: $38 / 17)$. Ninety-five patients received PEGIFN alpha and Ribavirin (RBV). Twenty-six patients received PEG-IFN alpha-2a alone. SVR was defined as being negative for serum HCV-RNA on RT-PCR at 24 weeks after the End of Therapy (EOT). Fasting serum triglyceride (T-G), total-Cho, and apo-B were evaluated before starting therapy and at 24 weeks after EOT.

Results: SVR rates were 74\% (90/121). Serum levels of total-Cho and apo-B increased significantly $(p<0.05$ by Wilcoxon test) in patients infected with HCV genotypes 1 and 2 who achieved SVR at 24 weeks after EOT, as compared to before the start of therapy, but no increases were seen in non-SVR patients.

Conclusions: Infection with HCV genotypes 1 and 2 equally lowered serum levels of apo-B and total-Cho, which increased after HCV was successfully eradicated.

Keywords: Chronic hepatitis C; Cholesterol; Apolipoprotein-B; PEG-IFN; Ribavirin

\section{Introduction}

As hepatic biosynthesis of lipids has been suggested to play a role in the processes of infection and replication of Hepatitis C Virus (HCV) [1,2], HCV infection and serum lipid markers are thought to be related. Serum cholesterol (Cho) levels have been reported to be a predictor of Sustained Virologic Response (SVR) in patients with Chronic Hepatitis $\mathrm{C}(\mathrm{CHC})$ receiving antiviral therapy [3-6], but the precise mechanism for this phenomenon has not yet been confirmed.

We also reported recently that serum levels of total Cho (T-Cho) and its fraction increased in CHC patients showing SVR after treatment with interferon (IFN)-based therapy [7,8], and Corey et al. [9] reported similar observations.

The proteins associated with lipoproteins, known as apolipoproteins (apos), are required for the assembly, structure, and function of lipoproteins, and apos activate enzymes important in lipoprotein metabolism. It is known that apo-B is the major structural protein in chylomicron, Very Low Density Lipoprotein (VLDL)Cho, Intermediate Density Lipoprotein (IDL)-Cho and Low Density Lipoprotein (LDL)-Cho, which are synthesized in the liver.

The goal of the present study was to clarify how serum levels of lipid markers change in CHC patients showing SVR after treatment with IFN-based therapy.

\section{Patients and Methods}

\section{Patients}

The study included 121 consecutive patients with $\mathrm{CHC}$ who were infected with genotype 1 ( $n=66$; male/female: 40/26; age: 28 to 72 years) having baseline HCV-RNA ranging from 3.9 to $7.4 \mathrm{log}$ copies $/ \mathrm{ml}$, as quantified by real time (RT)-PCR (lower detection limit: 1.2 log copies/ ml, upper limit: $9.1 \mathrm{log}$ copies/ml; TaqMan; Chugai Pharmaceutical Co., Ltd., Tokyo, Japan), or with genotype 2 ( $n=55$; male/female: $38 / 17$; age: 31 to 76 years) having baseline HCV-RNA ranging from 3.2 to 7.1 $\log$ copies/ml, as quantified by RT-PCR. All patients were positive for anti-HCV antibody on testing with third-generation enzyme-linked immunosorbent assay and were positive for serum HCV-RNA on RTPCR, but were negative for hepatitis B surface antigen. Patients were excluded if they were known to be homosexual or were intravenous drug users, if they were positive for antinuclear antibodies, or if they had metabolic liver dysfunction, history of familial hyperlipidemia, HIV co-infection or renal dysfunction. Furthermore, patients were excluded if they were taking lipid-lowering drugs, if they were taking hypoglycemic agents, or if they had a history of habitual alcohol abuse (daily alcohol consumption $>20 \mathrm{~g} /$ day in men and $>10 \mathrm{~g} /$ day in women).

*Corresponding author: Kanayama K Division of Gastroenterology and Hepatology, Department of Internal Medicine, Toho University School of Medicine Faculty of Medicine, 6-11-1, Omorinishi, Otaku, Tokyo, 143, Japan, Tel: 81-33762-4151; Fax: 81-3-3763-8542; E-mail: iskoji377@med.toho-u.ac.jp

Received March 21, 2012; Accepted August 29, 2012; Published August 31 2012

Citation: Kogame M, Ishii K, Kanayama K, Shinohara MI, Sumino Y (2012) Elevation of Serum Apolipoprotein B after Successful Eradication of Hepatitis $C$ Virus in Patients with Chronic Hepatitis C Treated by IFN-Based Therapy. J Liver 1:113. doi:10.4172/2167-0889.1000113

Copyright: () 2012 Ishii K, et al. This is an open-access article distributed unde the terms of the Creative Commons Attribution License, which permits unrestricted use, distribution, and reproduction in any medium, provided the original author and source are credited. 
Citation: Kogame M, Ishii K, Kanayama K, Shinohara MI, Sumino Y (2012) Elevation of Serum Apolipoprotein B after Successful Eradication of Hepatitis C Virus in Patients with Chronic Hepatitis C Treated by IFN-Based Therapy. J Liver 1:113. doi:10.4172/2167-0889.1000113

Page 2 of 5

Of the 121 patients, 82 had undergone percutaneous liver biopsy before therapy under ultrasonographic control, and tissue specimens thus obtained were scored according to the Histology Activity Index (HAI) of Knodell et al. [10], and were divided into three grades (Grade 1 for HAI scores of 1-3; Grade 2 for HAI scores of 4-8; and Grade 3 for HAI scores of 9 or more). Specimens were also divided into four groups from stage 1 to stage 4 based on the fibrosis score of Desmet [11].

\section{IFN regimens}

After providing informed consent, 58 patients received PEGIFN alpha-2b (PegIntron ${ }^{\circledR}$; MSD K.K., Tokyo, Japan) at weekly doses adjusted for body weight according to the manufacturer's instructions ( $45 \mathrm{~kg}$ or less $=60 \mu \mathrm{g} /$ dose; 46 to $60 \mathrm{~kg}=80 \mu \mathrm{g} / \mathrm{dose} ; 61$ to $75 \mathrm{~kg}=100$ $\mu \mathrm{g} / \mathrm{dose} ; 76$ to $90 \mathrm{~kg}=120 \mu \mathrm{g} / \mathrm{dose}$; and 91 or more $=150 \mu \mathrm{g} / \mathrm{dose})$ in combination with oral ribavirin (Rebetol ${ }^{\mathbb{R}}$; MSD, K.K.) at daily doses adjusted for body weight according to the manufacturer's instructions ( $60 \mathrm{~kg}$ or less $=600 \mathrm{mg} /$ day; 61 to $80 \mathrm{~kg}=800 \mathrm{mg} /$ day; and $81 \mathrm{~kg}$ or more $=1,000 \mathrm{mg} /$ day) for 48 weeks for HCV genotype 1 and high viral load (serum HCV-RNA >5.0 log copies/ml), and for 24 weeks for HCV genotype 2 and high viral load.

Thirty-seven patients received PEG-IFN alpha-2a (Pegasys ${ }^{\circledR}$; Chugai Pharmaceutical Co., Ltd.) at $180 \mu \mathrm{g}$ per week in combination with ribavirin (Copegus ${ }^{\circledR}$; Chugai Pharmaceutical Co., Ltd.) given orally at daily doses adjusted for body weight according to the manufacturer's instructions ( $60 \mathrm{~kg}$ or less $=600 \mathrm{mg} /$ day; 61 to $80 \mathrm{~kg}=800 \mathrm{mg} /$ day; and $81 \mathrm{~kg}$ or more $=1,000 \mathrm{mg} /$ day) for 48 weeks for HCV genotype 1 and high viral load, and for 24 weeks for HCV genotype 2 and high viral load.
The remaining 26 patients received PEG-IFN alpha-2a $\left(\right.$ Pegasys $\left.^{\circledR}\right)$ alone at $180 \mu \mathrm{g}$ per week for 24 to 48 weeks for HCV genotype 1 or genotype 2 and low viral load (serum HCV-RNA $<4.9$ log copies/ml).

Some patients needed slight adjustment of the PEG-IFN and RBV doses, because of decreases in leukocyte count, platelet count or hemoglobin during therapy.

Serum HCV-RNA was measured using RT-PCR before the start of therapy and every 4 weeks thereafter until the End of Therapy (EOT), as well as at 24 weeks after EOT. SVR was defined as being negative for serum HCV-RNA by RT-PCR at 24 weeks after EOT.

\section{Assay}

Fasting serum total Cho (T-C), triglyceride (T-G), and apo-A1, -A2 and $-\mathrm{B}$ were evaluated [12] before the start of IFN therapy and at 24 weeks after EOT. To assess hepatic synthetic function, serum albumin and peripheral blood prothrombin time (PT: \%) were measured by standard methods before starting therapy and at 24 weeks after EOT.

\section{Statistical analysis}

Results shown in the table 1 are presented as medians and $10^{\text {th }}$ to $90^{\text {th }}$ percentiles.

Comparisons between two groups were performed by nonparametric Mann-Whitney test or Wilcoxon's signed rank test. Multiple comparisons were performed by parametric Tukey's test. In all analyses, a probability value of less than 0.05 was considered to indicate statistical significance.

\begin{tabular}{|c|c|c|c|c|c|}
\hline & & & Genotype 1 & Genotype 2 & \\
\hline No. of patients & & & 66 & 55 & \\
\hline Age & $(y)$ & Median & $55(41-66)$ & $54(40-67)$ & NS\# \\
\hline Sex & $(\mathrm{M} / \mathrm{F})$ & & $40 / 26$ & $38 / 17$ & $\mathrm{NS}^{*}$ \\
\hline \multicolumn{6}{|l|}{ Laboratory data } \\
\hline HCV level & $(\mathrm{KIU} / \mathrm{ml})$ & & $6.3(4.8-6.9)$ & $5.5(3.8-6.6)$ & $p<0.01^{*}$ \\
\hline AST & $(\mathrm{IU} / \mathrm{I})$ & Median & $49(24-86)$ & $54(26-86)$ & NS\# \\
\hline ALT & $(\mathrm{IU} / \mathrm{I})$ & Median & $54(25-117)$ & $58(25-151)$ & NS\# \\
\hline ChE & $(I U / I)$ & Median & $252(111-380)$ & 295 (205-397) & NS\# \\
\hline Albumin & $(\mathrm{g} / \mathrm{dl})$ & Median & $4.2(3.6-4.6)$ & $4.2(3.4-4.6)$ & NS\# \\
\hline T-Cho & $(\mathrm{mg} / \mathrm{dl})$ & Median & $162(131-212)$ & $166(137-219)$ & NS\# \\
\hline T-G & $(\mathrm{mg} / \mathrm{dl})$ & Median & $87(63-181)$ & $96(54-246)$ & NS\# \\
\hline \multicolumn{6}{|l|}{ Peripheral Blood } \\
\hline WBC & $\left(10^{3} / \mu \mathrm{l}\right)$ & Median & $4.8(3.4-7.7)$ & $5.2(3.5-6.9)$ & NS\# \\
\hline RBC & $\left(10^{6} / \mu \mathrm{l}\right)$ & Median & $4.5(3.6-5.0)$ & $4.6(3.9-5.2)$ & NS\# \\
\hline PLT & $\left(10^{4} / \mu \mathrm{l}\right)$ & Median & $15.1(8.2-25.6)$ & $17.1(10.2-26.6)$ & NS\# \\
\hline PT & $(\%)$ & Median & $94(79-112)$ & $98(73-114)$ & NS\# \\
\hline \multicolumn{6}{|l|}{ Pathological findings } \\
\hline Activity (1/2/3/none) & & & $(22 / 23 / 0 / 21)$ & $(16 / 21 / 0 / 18)$ & $\mathrm{NS}^{*}$ \\
\hline Staging (1/2/3/4/none) & & & $(18 / 13 / 1 / 13 / 21)$ & $(21 / 7 / 3 / 6 / 18)$ & $\mathrm{NS}^{*}$ \\
\hline \multicolumn{6}{|l|}{ IFN regimen } \\
\hline \multicolumn{2}{|c|}{ Ribavirin+PEG-IFN-alpha $2 b(n=)$} & & 29 & 29 & \\
\hline Period & (week) & & $48(48-72)$ & $24(24-48)$ & $p<0.01$ \\
\hline \multicolumn{2}{|c|}{ Ribavirin+Peg- IFN-alpha $2 a(n=)$} & & 33 & 4 & \\
\hline Period & (wk) & & $48(32-72)$ & $48(48-48)$ & NS\# \\
\hline \multicolumn{2}{|l|}{ PEG-IFN-alpha alone $\quad(n=)$} & & 4 & 22 & \\
\hline Period & (week) & & $24(24-24)$ & $24(24-24)$ & NS\# \\
\hline \multicolumn{6}{|l|}{ Efficacy of therapy } \\
\hline (SVR/ Relapser / NVR) & & & $(40 / 13 / 13)$ & $(51 / 3 / 1)$ & $p<0.01$ \\
\hline
\end{tabular}

In parentheses, range represents $10^{\text {th }}$ and $90^{\text {th }}$ percentiles. 


\section{Results}

\section{Response of $\mathrm{CHC}$ to treatment}

Of the 66 CHC patients (61\%) infected with HCV genotype 1 , 40 achieved SVR, while 50 of 55 CHC patients (91\%) infected with genotype 2 achieved SVR.

\section{Changes in serum lipids in CHC patients}

There were no significant differences in baseline serum levels of T-Cho, T-G, apo-A1, apo-A2 and apo-B between CHC patients infected with HCV genotypes 1 and 2. However, the serum levels of T-Cho and apo-B had increased significantly ( $\mathrm{p}<0.05$, Wilcoxon's test) at 24 weeks after EOT, as compared to before the start of therapy, in CHC patients with both HCV genotypes 1 and 2 (Figure 1a and Figure 1e). Serum levels of apo-A2 had decreased significantly ( $<<$ 0.05 by Wilcoxon's tests) at 24 weeks after EOT, as compared to before the start of therapy, in $\mathrm{CHC}$ patients with only HCV genotype 1, while there were no differences between pre-therapy values and those at 24 weeks after EOT in CHC patients infected with genotype 2 (Figure 1d).

There were no significant differences in serum levels of T-G or apo-A 1 before the start of therapy and at 24 weeks after EOT in $\mathrm{CHC}$ patients infected with either HCV genotype 1 or 2 (Figure $1 \mathrm{~b}$ and Figure 1c).

\section{Changes in other serum liver marker in $\mathrm{CHC}$ patients}

Serum levels of albumin showed a median value of $4.2 \mathrm{~g} / \mathrm{dl}\left(10^{\text {th }}\right.$ $90^{\text {th }}$ range: $3.7-4.6 \mathrm{~g} / \mathrm{dl}$ ) before the start of therapy, and a median $4.4 \mathrm{~g} /$ $\mathrm{dl}\left(10^{\text {th }}-90^{\text {th }}\right.$ range: $\left.3.9-4.7 \mathrm{~g} / \mathrm{dl}\right)$ at 24 weeks after EOT in SVR patients, while albumin levels were a median $4.0 \mathrm{~g} / \mathrm{dl}\left(10^{\text {th }}-90^{\text {th }}\right.$ range: $3.2-4.5 \mathrm{~g} /$ $\mathrm{dl})$ before the start of therapy and a median $4.0 \mathrm{~g} / \mathrm{dl}\left(10^{\text {th }}-90^{\text {th }}\right.$ range: $3.2-4.3 \mathrm{~g} / \mathrm{dl}$ ) at 24 weeks after EOT in non-SVR patients.

Peripheral blood PT was a median $96 \%\left(10^{\text {th }}-90^{\text {th }}\right.$ range: $75 \%-$ $114 \%)$ before the start of therapy and a median $97 \%\left(10^{\text {th }}-90^{\text {th }}\right.$ range: $82 \%-111 \%)$ at 24 weeks after EOT in SVR patients, while PT was a median $93 \%\left(10^{\text {th }}-90^{\text {th }}\right.$ range: $\left.79 \%-111 \%\right)$ before the start of therapy and a median $90 \%\left(10^{\text {th }}-90^{\text {th }}\right.$ range: $\left.79 \%-117 \%\right)$ at 24 weeks after EOT in non-SVR patients. There were no significant differences in serum

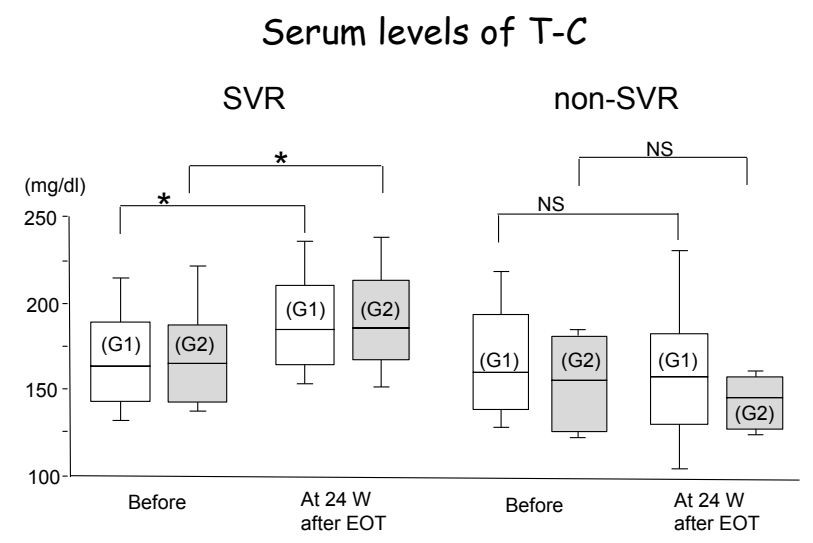

Figure 1a: Serum levels of Total Cholesterol (T-Cho) before the start of therapy and at 24 weeks after the End of Therapy (EOT) in Chronic Hepatitis C (CHC) patients infected with genotypes 1 and 2 who showed SVR and non-SVR.

Each box represents the range from the $2^{\text {nd }}$ to $3^{\text {rd }}$ quartiles $\left(25^{\text {th }}\right.$ to $75^{\text {th }}$ percentile) and each horizontal line represents the median. Upper and lower bars represent the $10^{\text {th }}$ and $90^{\text {th }}$ percentiles.

NS: No significant differences by Wilcoxon's signed rank test.

\section{Serum levels of $T-G$}

SVR

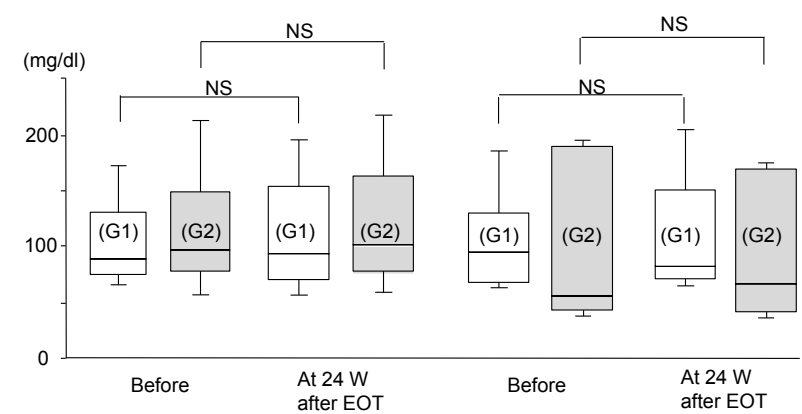

Figure 1b: Serum levels of triglyceride (T-G) before the start of therapy and at 24 weeks after EOT in CHC patients infected with genotypes 1 and 2 who showed SVR and non-SVR.

NS: No significant differences by Wilcoxon's signed rank.

\section{Serum levels of Apo-A1}

\section{SVR}

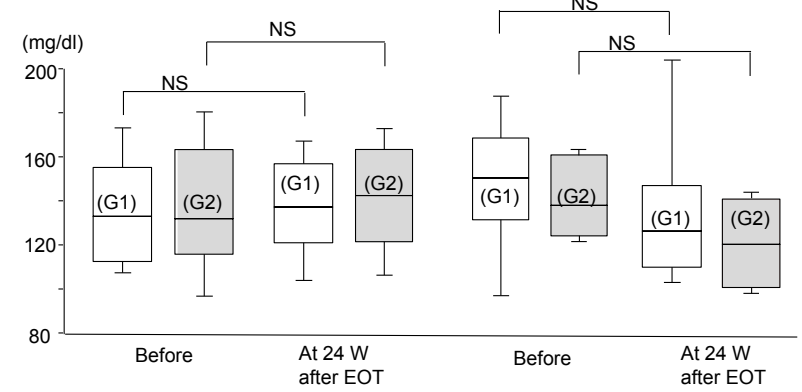

Figure 1c: Serum levels of apo-A1 before the start of therapy and at 24 weeks after EOT in CHC patients infected with genotypes 1 and 2 who showed SVR and non-SVR.

NS: No significant differences by Wilcoxon's signed rank test.

levels of albumin or peripheral blood PT between pre-treatment values and those at 24 weeks after EOT in either group.

\section{Discussion}

The present study demonstrated that serum levels of T-Cho and apo-B increased significantly in patients infected with genotypes 1 and 2 who achieved SVR at 24 weeks after EOT, as compared to pretherapy levels, but such increases were not seen in non-SVR patients. In addition, serum levels of apo-A2 decreased significantly in patients infected with only genotype 1 who achieved SVR at 24 weeks after EOT, as compared to pre-therapy levels. These changes suggest that infection with HCV genotypes 1 and 2 equally lowered host serum levels of T-Cho and apo-B, which increased after HCV was successfully eradicated. It was also suggested that HCV genotype 1 infection increased serum levels of apo-A2, which decreased at 24 weeks after EOT following successful HCV eradication, but such increases were not seen in CHC patients with HCV genotype 2 infection. We previously reported that serum T-Cho, including LDL- and VLDL-Cho, increased at 24 weeks after EOT when SVR was obtained in patients with CHC treated with IFN-based therapy [7,8], irrespective of their HCV genotypes. Corey et al. [9] also reported that serum T-Cho in CHC patients infected with genotype 1 increased significantly more at 24 weeks after EOT. 


\section{Serum levels of Apo-A2}

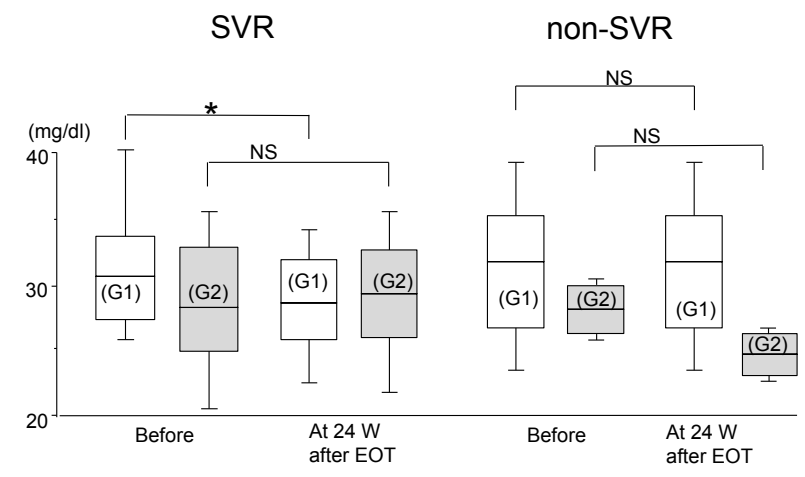

Figure 1d: Serum levels of apo-A2 before the start of therapy and at 24 weeks after EOT in $\mathrm{CHC}$ patients infected with genotypes 1 and 2 who showed SVR and non-SVR.

NS: No significant differences by Wilcoxon's signed rank test.

$※$ : Significant difference by Mann-Whitney test $(p<0.05)$.

\section{Serum levels of Apo-B}

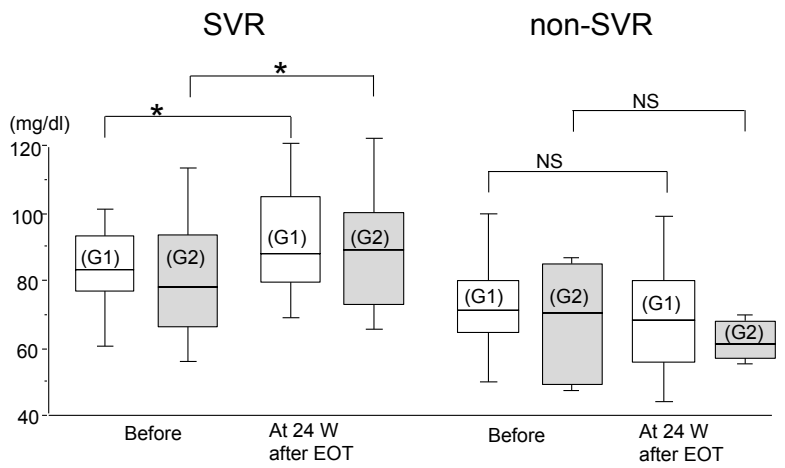

Figure 1e: Serum levels of apolipoprotein (apo)-B before starting therapy and at 24 weeks after EOT in CHC patients infected with genotypes 1 and 2 who showed SVR and non-SVR.

$※$ : Significant difference by Wilcoxon's signed rank test $(p<0.05)$.

It is known that apo-B is present as a lipoprotein in LDL-Cho and VLDL-Cho. VLDL-Cho is secreted into the bloodstream after assembly with apo-B. HCV is reported to cause acquired Hypo Beta Lipoproteinemia (HBL), in which fat accumulates in hepatocytes, steatosis develops and serum levels of apo-B decrease in those infected with HCV genotype $3[13,14]$ or HCV genotype 1 [12]. Serum levels of these lipid markers increased when SVR is obtained among treated CHC patients [13]. In the present study, serum levels of T-Cho and apo B increased equally in CHC patients infected with HCV genotypes 1 and 2 who achieved SVR. Therefore, it has been suggested that both HCV genotype 1 and HCV genotype 2 equally inhibit assembly and/or secretion of VLDL-Cho, and that serum levels of T-Cho and apo-B decrease before the start of IFN-based therapy. These levels then increase after HCV is successfully eradicated from CHC patients. The precise mechanism through which HCV induces acquired HBL remains unknown, but this mechanism should soon be elucidated, as interactions between $\mathrm{HCV}$, apo-B and microsomal triglyceride transfer protein are now being clarified $[15,16]$.

It was recently reported that apo-B acts as a molecular link between lipid-induced endoplasmic reticulum stress and hepatic insulin resistance [17], both of which are known to be caused by HCV infection $[18,19]$. More recently, it was reported that host cellular factor apo-B messenger RNA-editing enzyme catalytic polypeptidelike $3 \mathrm{G}$ (hA3G), a cytidine deaminase, increases in patients with $\mathrm{HCV}$ infection. hA3G appears to be a cellular restricting factor against $\mathrm{HCV}$, however, this enzyme is known to be degraded by viruses [20]. If HCV has been eliminated from hepatocytes such as $\mathrm{CHC}$ patients having SVR, apo-B may be released into the blood as a result of improvement of metabolism in hepatocytes.

In the present study, serum levels of apo-A2 had decreased significantly at 24 weeks after EOT, as compared to before the start of therapy, in CHC patients with only HCV genotype 1, but not in $\mathrm{CHC}$ patients infected with genotype 2. It is reported to be inverse relationship between LDL cholesterol and HDL cholesterol [21]. Therefore, serum HDL-C which is including Apo-A2 might be compensatory increased with decreased serum LDL cholesterol which is including apo-B before the start of treatment, and serum Apo-A2 included in HDL-C decreased with increased Apo-B included in LDL-C after successful elimination of HCV. However, it must be left to the future study of whether this phenomenon occurs only in CHC patients infected with HCV genotype 1 .

When cholesterol levels are discussed, the relationship with liver function becomes a problem, as serum cholesterol levels tend to decrease in patients who show histological progression of chronic liver disease [22]. In the present study, serum albumin and peripheral blood PT were measured in order to assess hepatic synthetic function, but there were no significant differences in these parameters between baseline and assessment. Therefore, the changes in serum lipid markers do not necessarily depend on amelioration of liver function brought by eradication of $\mathrm{HCV}$.

In conclusion, our results suggest that HCV genotypes 1 and 2 equally reduce serum levels of T-Cho and apo-B, which increase after HCV is successfully eradicated.

\section{References}

1. Kapadia SB, Chisari FV (2005) Hepatitis C virus RNA replication is regulated by host geranylgeranylation and fatty acids. Proc Natl Acad Sci U S A 102: 2561-2566.

2. Barba G, Harper F, Harada T, Kohara M, Goulinet S, et al. (1997) Hepatitis C virus core protein shows a cytoplasmic localization and associates to cellular lipid storage droplets. Proc Natl Acad Sci U S A 94: 1200-1205.

3. Minuk GY, Weinstein S, Kaita KD (2000) Serum cholesterol and low-density lipoprotein cholesterol levels as predictors of response to interferon therapy for chronic hepatitis C. Ann Intern Med 132: 761-762.

4. Gopal K, Johnson TC, Gopal S, Walfish A, Bang CT, et al. (2006) Correlation between beta-lipoprotein levels and outcome of hepatitis $\mathrm{C}$ treatment. Hepatology 44: 335-340.

5. Economou M, Milionis H, Filis S, Baltayiannis G, Christou L, et al. (2008) Baseline cholesterol is associated with the response to antiviral therapy in chronic hepatitis C. J Gastroenterol Hepatol 23: 586-591.

6. Akuta N, Suzuki F, Kawamura Y, Yatsuji H, Sezaki H, et al. (2007) Predictive factors of early and sustained response to peginterferon plus ribavirin combination therapy in Japanese patients infected with hepatitis $\mathrm{C}$ virus genotype 1b: Amino acid substitutions in the core region and low-density lipoprotein cholesterol levels. J Hepatol 46: 403-410.

7. Ishii K, Takamura N, Higami K, Mtsumaru K, Nagai H, et al. (2007) Change of serum cholesterol fractions after sustained response to IFN therapies in patients with chronic Hepatitis C. Gastroenterology 132: A793.

8. Sawa M, Ishii K, Sumino $Y(2010)$ Change in serum lipid markers in patients with chronic hepatitis $C$ treated with interferon-based therapy. J Med Soc Toho 57: 3-11.

9. Corey KE, Kane E, Munroe C, Barlow LL, Zheng H, et al. (2009) Hepatitis 
Citation: Kogame M, Ishii K, Kanayama K, Shinohara MI, Sumino Y (2012) Elevation of Serum Apolipoprotein B after Successful Eradication of Hepatitis C Virus in Patients with Chronic Hepatitis C Treated by IFN-Based Therapy. J Liver 1:113. doi:10.4172/2167-0889.1000113

Page 5 of 5

C virus infection its clearance alter circulating lipids: Implication for long-term follow-up. Hepatology 50: 1030-1037.

10. Knodell RG, Ishak KG, Black WC, Chen TS, Craig R, et al. (1981) Formulation and application of a numerical scoring system for assessing histological activity in asymptomatic chronic hepatitis. Hepatology 1: 431-435.

11. Desmet VJ, Gerber M, Hoofnagle JH, Manns M, Scheuer PJ (1994) Classification of chronic hepatitis: diagnosis, grading and staging. Hepatology 19: $1513-1520$

12. Moriya K, Shintani Y, Fujie H, Miyoshi H, Tsutsumi T, et al. (2003) Serum lipid profile of patients with genotype $1 \mathrm{~b}$ hepatitis $\mathrm{C}$ viral infection in Japan. Hepatol Res 25: 371-376.

13. Serfaty L, Andreani T, Giral P, Carbonell N, Chazouillères O, et al. (2001) Hepatitis $C$ virus induced hypobetalipoproteinemia: a possible mechanism for steatosis in chronic hepatitis C. J Hepatol 34: 428-434.

14. Petit JM, Benichou M, Duvillard L, Jooste V, Bour JB, et al. (2003) Hepatitis $C$ virus-associated hypobetalipoproteinemia is correlated with plasma load, steatosis, and liver fibrosis. Am J Gastroenterol 98: 1150-1154.

15. Ratziu V, Trabut JB, Poynard T (2004) Fat, diabetes, and liver injury in chronic hepatitis C. Curr Gastroenterol Rep 6: 22-29.

16. Qu W, Federico L, Naples M, Avramoglu RK, Meshkani R, et al. (2008) Phosphatase and tensin homolog (PTEN) regulates hepatic lipogenesis microsomal triglyceride transfer protein, and the secretion of apolipoprotein B-containing lipoproteins. Hepatology 48: 1799-1809.

17. Su Q, Tsai J, Xu E, Qiu W, Bereczki E, et al. (2009) Apolipoprotein B100 acts as a molecular link between lipid-induced endoplasmic reticulum stress and hepatic insulin resistance. Hepatology 50: 77-84.

18. von dem Bussche A, Machida R, Li K, Loevinsohn G, Khander A, et al. (2010) Hepatitis C virus NS2 protein triggers endoplasmic reticulum stress and suppresses its own viral replication. J Hepatol 53: 797-804.

19. Bridge SH, Sheridan DA, Felmlee DJ, Nielsen SU, Thomas HC, et al. (2011) Insulin resistance and low-density apolipoprotein B-associated lipoviral particles in hepatitis $C$ virus genotype 1 infection. Gut 60: 680-687.

20. Peng ZG, Zhao ZY, Li YP, Wang YP, Hao LH, et al. (2011) Host apolipoprotein $B$ messenger RNA-editing enzyme catalytic polypeptide-like $3 G$ is an innate defensive factor and drug target against hepatitis $C$ virus. Hepatology 53: 10801089

21. Younis NN, Soran H, Charlton-Menys V, Sharma R, Hama S, et al. (2012) High-density lipoprotein impedes glycation of low-density lipoprotein. Diab Vasc Dis Res.

22. D’Arienzo A, Manguso F, Scaglione G, Vicinanza G, Bennato R, et al. (1998) Prognostic value of progressive decrease in serum cholesterol in predicting survival in Child-Pugh C viral cirrhosis. Scand J Gastroenterol 33: 1213-1218. 